\title{
Globalization, Civil Society and Citizenship in Turkey: Actors, Boundaries and Discourses
}

\section{E. FUAT KEYMAN \& AHMET ICDUYGU}

To cite this article: E. FUAT KEYMAN \& AHMET ICDUYGU (2003) Globalization, Civil Society and Citizenship in Turkey: Actors, Boundaries and Discourses, Citizenship Studies, 7:2, 219-234, DOI: $10.1080 / 1362102032000065982$

To link to this article: https://doi.org/10.1080/1362102032000065982

曲 Published online: 01 Jul 2010.

Submit your article to this journal $\pi$

Џlll Article views: 1112

4 Citing articles: 49 View citing articles 


\title{
Globalization, Civil Society and Citizenship in Turkey: Actors, Boundaries and Discourses
}

\author{
E. FUAT KEYMAN and AHMET ICDUYGU
}

In recent years, civil society has become one of the most important concerns of academic and public discourse. It would not be a mistake to propose that today there is a strong, effective and even over-glorified talk about and a global agenda for civil society and its role in the process of creating a better and humane world. In this talk and agenda the main intention is to reinvigorate and strengthen civil society politically, organizationally and normatively as a counter-hegemonic and resistance movement against the state-centric world. This paper argues that Turkey does not constitute an exception in this context. Rather, it provides an illuminating case-study in which the crisis of the state-centric modernity has given rise to the elevation of civil society to the status of being an extremely important actor and arena for the democratization of the state-society relations. However, on the basis of the three-year-long research (1999-2002) we have done on 'the impacts of globalization on Turkey', the paper also argues that the role of civil society in the process of democratization should be considered a necessary but not a sufficient condition, insofar as it contains both democratic and essentialist discourses about citizenship and identity. In order to substantiate these arguments, the paper will first outline the internal and external factors that have paved the way to the emergence and the increasing importance of civil society in Turkey, and then will shift its attention to the question of 'the use and the abuse of civil society'. In seeking a proper answer to this question, the paper will focus on the discourses and strategies of different civil society organizations about state, society, citizenship and identity in Turkey.

As we enter the new millennium, it appears to be more and more difficult, if not impossible, to think of politics only with reference to the 'national context'. Such modern referents of politics as the nation-state, national identity and national economy have been losing their explanatory power for the analysis of social and political change, as a result of the process of increasing interconnect-

E. Fuat Keyman, Department of International Relations, Koç University, Rumeliçenen Yolu 34450, Sarýyer, Istanbul, Turkey.

Ahmet Icduygu, Department of Political Science, Bilkent University. 
edness of societies, making 'national context' vulnerable and exposed to global/ regional and local pressures. In fact, what David Held describes as globalization, that is, 'the widening, the deepening and the speeding up of the interconnectedness' in our increasingly globalized world, is forcing us to think of our societal affairs beyond 'the national context' (Held et al., 1999).

It can be argued, in this sense, that globalization constitutes a set of historical processes, generating important effects in the ways in which societal affairs in a given national setting are constructed, as well as in the mode in which they are analyzed. While the process of economic globalization, that is, the globalization of capital, is challenging and undermining the authority of nation-states by creating 'a borderless global market place', the process of cultural globalization is rendering the idea of national development problematic by giving rise to the emergence of 'alternative modernities', cultural identities and the clash between the universal Western values and the particular/local claims to authenticity. These processes also reflects on the formation of politics in a national setting, by creating 'the limits of politics' in terms of its boundaries and its actors (Strange, 1992). In this sense, we observe that as a conditioning factor of political action and discourse, globalization limits the ability of political actors both to maintain their dominant position in national politics, and to reduce and confine the boundaries of politics as 'a territorially-sovereign and nationally-bound activity'. ${ }^{1}$

As a result, we are no longer able to think of politics as a purely national in terms of its actors and its boundaries. Whereas the boundaries and the parameters of politics are being extended to global and local flows/interactions, its actors multiply to the extent that they include inter-, intra-national and global organizations, and their role and activities in solving problems related to the human condition. One of the important sites at which the changing nature of politics has occurred in a global-historical context is that of 'civil society', which has been elevated to the status of the 'key area' for the possible democratization of the world in which we live (Schechter, 1999).

It has been argued that as an area of public deliberation, civil society has to be strengthened against the nation-state which has been the dominant focus/actor of politics in modernity, in order to create the possibility of democratizing the state-society/individual relations (Keyman, 2000a). This argument has been based upon the common contention/assumption in academic and public discourse that in time when the problems of modernity that have become global/local in their nature and scope are increasingly requiring global solutions, the nationstate itself is not capable at all any more of coping effectively with them and providing effective policies to solve them. These problems, coming into existence as what Anthony Giddens has called 'the radical consequences of modernity', being felt in every and each sphere of life, and generating crucial changes in our relations with nature, with different cultures and identities, as well as with ourselves, as the argument follows, have paved the way to the emergence of the calls for participatory democracy, new actors beyond the nation-state and the new language/discourse of politics (Giddens, 1987). It is on the basis of this argument that civil society and civil society organizations have been brought to the fore, even over-glorified, as a necessary condition and an 
important actor for 'eradicating poverty, promoting democracy and good governance, resolving social conflict and protecting human rights'.

It would not be a mistake to propose that today there is a strong and effective talk about and a global agenda for civil society, even about the evolving global civil society, and its role in the process of creating a better and 'humane world', in which the main intention is to reinvigorate and strengthen civil society politically, organizationally and normatively as a counter-hegemonic and resistance movement against the 'state-centric world' (Dower, 1998; Ehrenberg, 1999; Koh and Slye, 1999). It is however a mistake to attribute in an ipso facto manner 'positivity' to civil society, insofar as it involves not only democratic discourses, but also essentialist identity claims, voiced by religious and ethnic fundamentalism, and arguing for reconstructing the state-society/individual relations in a communitarian basis. In this sense, we should acknowledge that the global talk about civil society contains both 'the use and the abuse of civil society', and therefore that civil society is a necessary but not a sufficient condition for democracy (Keyman, 2000b).

It can be suggested here that Turkey, in this context, is not an exception: on the contrary, during the last decade, Turkish society has undergone rapid social/cultural, economic and political change. Moreover, as we will see, the sources of change are located in the global-national-local context, giving rise not only to the legitimacy crisis of the Turkish state and the emergence of the alternative claims to Turkish modernity, but also to the increasing ambivalence embedded in the process of Turkey's integration into the European Union as a full member. One of the important sites where we observe clearly the process of change and its manifestations in Turkey is that of civil society, which has been growing since the 1980s, especially during the 1990s, in terms of its qualitative and quantitative importance for making Turkish society more liberal and democratic than before. Indeed, there are almost 3000 civil society organizations in Turkey today, whose activities involve a number of issues, ranging from human rights to democratization, from peace to environment, from issue-specific problems to even meta-societal visions such as Westernization, Atatürkism, nationalism, and Islamization. Quantitatively, civil society organizations have begun to play an important role in articulating and representing the various ideological interests and political demands voiced by different segments of society, as well as in transmitting to the political actors the societal calls for democratization and the need for effective governing. In this sense, we can suggest that the increasing role of civil society in Turkey especially during the 1990s has created 'the relative autonomization of economic activities, societal groups and cultural identities', which has given rise to 'an autonomous societal sphere' by realizing the shift in the focus of political practice 'from the state to society' (Göle, 1994).

It should be pointed out, however, that the emergence of 'an autonomous societal sphere' in Turkish politics as an outcome of the increasing activities and importance (at least in a normative sense) of civil society organizations should not be taken as a given positive development. Instead, while recognizing the importance of this development for democratization, we should also recognize the possibility of the use and the abuse of civil society, and therefore that we 
should analyze critically the actors of civil society in terms of their discourses and strategies. In other words, as we will elaborate in detail, we should recognize that the emergence of civil society involves not only the possibility of democratization, but also serious problems, insofar as it constitutes a 'discursive space' both for democratic forces and for religious and the ethnonationalist political strategies to voice their essentialist and anti-democratic identity claims. For this reason, we suggest that civil society in Turkey involves a serious 'boundary problem', since it functions not only as a necessary condition for democratization, but also as 'an important site' for the activities of anti-democratic forces to put their identity politics in practice. ${ }^{3}$

In order to substantiate this argument, we will first outline the internal and external factors that have paved the way to the emergence and the increasing importance of civil society in Turkey. Then, we will focus on the use and the abuse of civil society by looking at the discourses and the strategies of different civil society organization, in a way to delineate the way in which the boundary problem of civil society has occurred. This will allow us to suggest that the reason for the boundary problem is in fact historical, insofar as it is related to the larger problem of 'citizenship' in Turkey. For this reason, in the last section, we will attempt to provide a brief explanation of the (republican) citizenship regime in Turkey, which has played an important role in the transformation of civil society into a 'site' for the activities of political actors to exercise their identity-based political strategies. In conclusion, we will make a set of suggestions for the possibility of democratization in Turkey, for which, we still believe, civil society should be supported as a 'necessary condition'.

\section{Situating Civil Society in a Global-Historical Context}

The historical context, in which identity politics has occurred and influenced Turkish social and political life, is not only national, but also global in nature. The emergence of civil society is also embedded in this global context. More particularly, it has been suggested that four distinct but nevertheless interrelated processes have dictated both the direction of Turkish modernization since the 1980 s and the way in which civil society has become an important actor in Turkish politics. ${ }^{4}$ In this sense, these processes should be considered when analyzing the current state of Turkish politics, where the center-Right and center-Left political parties have continuously been declining in terms of their popular support and their ability to produce effective and convincing policies, while at the same time both the resurgence of identity politics and civil society have become strong and influential actors of social and political change.

The first process is 'the changing meaning of modernity', that is, 'the emergence of alternative modernities'. Civil society organizations and intellectuals agree that since the 1980s, the process of Turkish modernization involved new actors, new mentalities of development and new identity claims. This means, first, the emergence of the critique of the status of the secular-rational thinking as the exclusive source of modernity in Turkey, and second, the increasing strength of Islamic discourse both as a 'political actor' and as a 'symbolic foundation' for identity formation. On the other hand, the alteration in 
the meaning of modernity also manifested itself in the emergence of the language of civil society, civil rights, and democratization. Calls for the need to think of modernity in terms of democracy created a context for the upsurge of interest in civil society, citizenship, and the democratic self. Thus, since the 1980 s, but especially in the 1990s and today, not only has the hegemony of the secular and state-centric nature of Turkish modernity been challenged by alternative claims to identity, politics and society, but also and more importantly, we have seen the increasing presence of new actors with different societal visions and political discourses in Turkish politics (Keyman, 2000b). In additions to Islamic discourse with its political parties, there have emerged important and politically active civil society organizations, calling for the need to democratize the secular and state-centric model of Turkish modernity by making it more liberal, more civil and more compatible with the language of 'rights'. What marks the nature of Turkish politics today is the existence (or the emergence) of alternative claims to modernity in Turkish politics, carried out by new actors, new discourses and new strategies, all of which share the common suggestion that the secular and state-centric model of modernity is no longer able to govern society efficiently and democratically.

The second process is related to 'the legitimacy crisis of the strong-state tradition' in Turkey since the 1980s. Turkish modernization, since the beginning of the Republic, has been characterized by and has given rise to the 'strong-state tradition'. This tradition means, first, that the state has assumed the capacity of acting almost completely independent from civil society; second, that the state, rather than the government, has constituted 'the primary context of politics'; and third, that the state has played a significant role, been involved in the process of the production and reproduction of cultural life. The strong-state tradition has functioned as the organizing 'internal variable' of Turkish politics up until the 1980s. However, since the 1980s, the emergence of new actors, new mentalities and the new language of modernization, as well as democracy as a global point of reference in politics, has made culture and cultural factors an important variable in understanding political activities. Thus, the call for democratization as the main basis for the regulation of the state-society has become the global/local context for Turkish politics. This means that new actors acting at the global/local levels and calling for democratization have confronted the privileged role of state at the national level. In this sense, one of the important impacts of globalization on Turkish modernization has been, and still continues to be, the fact that the state has a legitimacy problem in maintaining its position as the primary context for politics, as a result of the shift towards civil society and culture as new reference points in the language and the terms of politics.

In order to understand these two processes, (1) the emergence of alternative modernities and (2) the legitimacy crisis of the strong-state tradition, we should also look at the changing structure of global relations in general, and the impact of the 'process of Turkey's integration into the European Union as a full member' on the formation of Turkish modernization since the 1990s. We could refer to both 'the process of European integration' and 'the process of globalization' as those constraining factors that have had important short-term and long-term impacts on the interaction of politics, polity and policy in the 1990s 
in Turkish politics. While the process of European integration means the emergence of the democratic mode of regulation of the state-society relations in Turkey, the process of globalization amounts to the intensification of economic, political and cultural relations across borders, which makes it very difficult, if not impossible, to think of politics without situating it into the global-nationallocal context (Keyman, 1997).

In order to have a better understanding of the impact of the process of European integration on Turkish politics and modernization, it is necessary to briefly touch upon the membership affair of Turkey with the European Union. After the European Council Meeting in Helsinki on 10-11 December 1999, Turkey has been declared as an official candidate for full membership to the European Union (hereafter, the EU). This decision started a process of preaccession including a transitional period of policy and legislation adoption and harmonization (Hale and Avci, 2001). The adoption and the implementation of the EU's social, political and economic policies are imperative and the basic requirement for the candidate state to become a full member. It should be pointed out, however, that among these requirements, the adoption of the EU acquis communitaire is of utmost importance, insofar as its implementation inevitably results in the modification of existing domestic policies and practices in various Justice and Home Affairs (Kirisci, 2002). In this process, the issues of citizenship and civil society are vitally important to the European Commission and its members. The importance to these issues has been reflected in the Accession Partnership Document (APD) ${ }^{5}$ issued in 2000, in which the EU Commission identified its short- and medium-term priorities, intermediate objectives and conditions. These priorities and objectives are non-negotiable, in that they constituted the basic criterion for the acceptance (as well as of the rejection) of a candidate country, such as Turkey, into the EU as a full member. As often referred to the political aspects of the 'Copenhagen criteria', the membership requires that Turkey must achieve a strong democratic stability, which ensures that the state governs society in accordance with the principle of the primacy of the rule of law, the protection of human rights and the respect for the minority rights. The Copenhagen criteria serve as a basis for the further democratization of the state-society relations in a given candidate country such as Turkey.

Since December 1999, the considerable political attention has been given in Turkey to the necessary reforms to meet the political sides of the Copenhagen criteria. It is within this context that in 2001, the government created the 'National Programme', ${ }^{6}$ which was designed to elevate the structure and quality of Turkish democracy to the level of European democracy by creating a legal foundation for the full protection of the individual rights and freedoms, the freedom of thought and expression, the freedom of association and peaceful assembly, and the enlargement of the space of civil society in Turkey. In the last year, the government also made some revolutionary political, administrative, and judicial reforms in the areas of human rights, democracy and the rule of law: these changes were directly related both to the further democratization of the state in Turkey and to the reconstruction of the republican model of citizenship in a way to make it more democratic and liberal. These reforms involved the 
abolishment of the death penalty, the elimination of the legal restrictions to the rights of different ethnic communities both to education and to broadcasting in their own mother tongues, and the granting and the non-Muslim religious foundations the right to acquire property. These reforms, which were made in accordance with the Copenhagen political criteria, are of utmost importance in the creation of a strong language of rights in Turkey, which has a positive impact on the democratization of the state and the enlargement of the space of civil society. At the same time, it should be admitted that these reforms also indicate that the sources of democratization in Turkey are no longer only national, but also global, and therefore that the EU plays an important role in the changing nature of the state-society relations in Turkey and functions as a powerful actor generating system-transforming impacts on Turkish politics.

Likewise, the process of globalization, especially the increasing globalization of markets and the growth of global communication, has yielded important consequences for the political process in Turkey, as it acted as a structural constraint on the economic policy options of the center-Right and center-Left political parties. Actors commonly maintain that one of the impacts of globalization on national politics is that it marks 'the limits of politics'. As a result of globalization, the differences that used to distinguish government policies from opposition policies are in a process of disappearance. This manifests itself especially and more clearly in policies regarding national economic issues, such as production, trade, and finance. Two important conclusions can be extrapolated here. The first is that the policy options of political parties are limited by globalization. Second, the globalizing world creates serious problems, which require effective and rationally formulated policies. Political parties alone cannot produce effective solutions to problems and issues, such as environmental risks, multiculturalism, and poverty, whose existence is increasingly affected by the very process of globalization. In this context, supranational actors and civil society organizations have become and act as 'actors of politics' as much as political actors. Turkish politics does not represent an exception: it is embedded in this process and globalization functions as a significant external variable for understanding the current state of the political process in Turkey.

These four factors, the emergence of alternative modernities, the legitimacy crisis of the strong-state tradition, the process of European integration and the process of globalization, are all situated at the intersection of the globalnational-local context. They indicate that since 1980, Turkish society has been subject to 'significant change', in which the process of globalization operates and generates impacts on societal affairs. By creating the global/local nexus whereby modernity is articulated by different discourses of self, identity and culture, globalization has brought about the possibility of the existence of alternative meanings attributed to modernity, that is, to the co-existence of different cultures with different interpretations of modernity. Thus the formation of Turkish modernization began to carry in it 'alternative modernities' with different political discourses of, and different future prospects for, Turkish social life. It is in this context, created by these four factors, that civil society has also become an important factor in Turkish politics. 


\section{Globalization and Civil Society Organizations}

As noted, since the 1980s, but especially during the 1990s, there has been an upsurge of interest in exploring alternative ways in which socio-political change in Turkey can be freed from the strong-state tradition. It is argued that socio-political change involves more actors taking place outside the "political center', and thus produces a more 'participatory political culture'. The sources of this interest are located not only in the general societal dissatisfaction with the strong-state tradition in Turkey, especially with respect to its increasing independence from society and its concomitant failure to respond to social and cultural demands and to cope with societal problems. The source for a more participatory culture was not only related to the general belief that the state has increasingly become unable to "cope with and manage effectively the changing nature of Turkish economic and cultural life'. It is argued that the sources were also 'global' in nature, insofar as they have coincided with the globalization of the interests and the activities of civil society organizations and non-governmental organizations. The emergence of what is called 'global civil society' has also provided both normative and institutional basis for the call for a more participatory culture in Turkey. In this sense, a reference to globalization in terms of its role in 'the creation of the language of politics, which is not exclusively associated with the state' constitutes a common denominator among civil society organizations. ${ }^{7}$

In other words, by creating a suitable platform for the 'information society', in which knowledge becomes as important as labor, and gets transmitted and disseminated throughout the world, cultural globalization makes politics and democracy more 'transitional' in terms of actors and strategies. Thus, civil society organizations find for themselves 'a space to do politics' between the failure of the nation-state and the transnationalization of politics and democracy, and attempt to include into the political agenda 'the issue and the problem areas around which they organize'. Civil society organizations are political actors, but, unlike political parties, they focus on specific issue areas, such as human rights, environment, peace, and the rights concerning gender, sexuality, ethnicity and culture. In this sense, civil society organizations promote a discourse of politics, founded upon the 'language of rights' which involves the protection and the expression of civil rights that the process of democratization requires. They promote a kind of (national and transnational) political activity, which is democratic, non-hierarchical, and participatory, and is initiated 'from the bottom up'. In this context, it is believed that the activities of civil society organizations have given rise to the process of the emergence of global civil society, which is sometimes characterized as a process of 'globalization-frombelow'.

In Turkey, the crisis of the strong-state tradition and the impacts of globalization have together contributed to the significant qualitative and quantitative increase in civil society organizations during the 1990s. Civil society organization have been considered (a) an 'indispensable element' of the process of democratization; (b) a 'necessary factor' to create stability in the relations between Turkey and the European Union; and (c) an 'important element' of the 
modernization and the liberalization of the Turkish state, so that it transforms itself into a political organization whose power and activities are 'accountable' to society. The discourse of civil society has been normatively supported and actively promoted in academic and public life in Turkey during the 1990s. Thus, civil society organizations have gained a '(political) actor-like quality' with normative and discursive power, influencing us to rethink the state-society/ individual relations beyond the strong-state tradition and by employing the globalization of the language of civil rights.

The tragic and devastating events of 1999 have also led us to think of civil society organizations seriously. The Marmara Earthquake on 17 August destroyed a large portion of the most industrial region of Turkey, causing almost 20,000 deaths and thereby creating one of the most tragic events of the century, and then there was the Düzce Earthquake on 12 November. These two disasters made it very clear to Turkish people that the strong state is in fact very weak in responding and coping with serious problems. This failure of the Turkish state to respond quickly to crisis situations has given rise to a common belief among people that civil society organizations and a more participatory political culture are necessary for the efficient and effective solution of the problems confronting Turkish society.

At the same time, the participation in research operations of several foreign search and rescue teams and the global outpouring of help to people who lost their families and homes, have created a point of articulation between globalization and civil society in Turkey. The large amount of financial and moral help coming from various societies, institutions and even individuals has created a significant shift in people's attitudes and behavioral patterns from a more nationalistic view of the world to a more transnationalist and universalistic approach to social relations. The normative value of civil society organizations and their call for the global acceptance of the language of civil rights and the participatory democracy has increased immensely in Turkey.

Having accounted for the reasons for the increasing importance of civil society organizations in Turkey, and its 'embeddedness' in what is called 'the global talk of civil society', it should be pointed out, however, that paradoxically, most of the civil society organizations in Turkey, in fact, see globalization as 'a process to be resisted in the long run' or as 'a problem to be seriously dealt with in order to make its impacts positive for Turkish society'. In other words, the general intellectual discourse of civil society, which sees globalization as one of the contributory factors for the development of civil society organizations in Turkey, does not correspond to the way in which civil society organizations themselves speak about the utility of globalization. In other words, civil society organizations appear to be 'quite skeptical' in the way in which they approach the question of the long-term impacts of cultural globalization. This skepticism sometimes operate in a strong fashion, to the extent that globalization is seen as nothing but a new form of imperialism creating undemocratic power relations in the world on behalf of rich countries. Sometimes, it takes the form of seeing globalization as an objective reality that produces both positive and negative impacts; positive in the sense of confronting the power of the strong state and creating a platform for the protection of civil rights, and negative in the 
sense of supporting the liberal hegemonic vision of the world, based on free market ideology. On the other hand, the leaders of some civil society organizations, such as citizenship initiatives, environmental organizations and organizations that are directly dealing with the problems of urban life, think of cultural globalization positively as a process 'internal' to their activities.

For example, 'Human Rights Organization', which receives global support for its activities, takes the strong skeptic position on globalization, and argues that although they support the existing global discourse on the protection of human rights, globalization in the long run serves the interests of the economically powerful countries in the world. Thus, the organization thinks that in the long run it is necessary that globalization should be resisted, in order to create democratic global governance. The other human rights organization, associated with Islamic discourse (Mazlum-Der), presents a softer version of skepticism, and argues that globalization provides a platform suitable for its activities, although the liberal discourse of human rights it promotes is problematic in dealing with cultural rights. On the other hand, the third human right organization (Helsinki Vatandaşlar Derneği), which was founded in Europe and operates in Turkey, views cultural globalization as a problem simultaneously generating positive and negative impacts for both the nation-state and civil society. That is, globalization cannot be rejected nor celebrated, but should be dealt with seriously in order to take advantage of its positive qualities, such as its support for the universalization of the discourse of civil rights.

To point out the differences between these three human rights organizations is important, in the sense that they also illuminate a general problem that confronts civil society organizations in Turkey, and this problem determines, to a large extent, their approach to the question of globalization. This problem is the 'boundary problem'; that is, to what extent civil society organizations in Turkey are in fact operating as a 'civil society organization' in terms of the scope and the content of their activities, their relation to the state, and their normative and ideological formations. The general definitional discourse on civil society in Turkey finds the institutional distinction between the state and society as a 'sufficient condition' for thinking of organizations taking place outside the boundaries of the state as civil society organizations. In fact, a large number of civil society organizations we have interviewed make use of this definition in describing themselves. However, this definition does not involve two important criteria, used in the literature to define civil society organizations, namely, that they are issue-specific organizations, and that they are not interested in creating or supporting ideological societal visions.

When we approach civil society organizations in Turkey on the basis of these two definitional criteria, we see that most of them act on the contrary, that is, their activities are not issue-based in scope and content; instead they are embedded in big societal visions. First of all, there are civil society organizations whose activities are framed, to a large extent, by big societal visions, such as, Kemalism, a modern Turkey, the protection of contemporary civilized life, the secular-democratic Turkey or Islamic order, Islamic life, a socialist Turkey, and Kemalist Woman, to name a few. Second, we see that while civil society organizations institutionally take place outside the state, they can have strong 
normative and ideological ties with state power. An illustrative example of this was the process of closing the Welfare Party, where strong ties were established between some civil society organizations, the military and the state. In this case, we witnessed how the search for what is good for society at large could be a mission around which civil society organizations center their activities.

In sum, as far as the relationship between globalization and civil society, there is a difference between the intellectual discourse about civil society and the scope and the content of the activities of civil society organizations. Intellectual discourse locates civil society in a space that has occurred between the legitimacy and the governability problem of the strong-state tradition and the changing nature of societal relations partly because of the processes of globalization, and thus sees civil society as a necessary condition for democratization, pluralism and multiculturalism. However, most of the civil society organizations act on the contrary with their ideologically and normatively-loaded discourses and strategies. This is precisely because of the boundary problem by which most of the civil society organizations are confronted today. Even though their numbers are increasing and they are becoming important actors, how civil they are still remains uncertain. One of the crucial reasons for this boundary problem, as we will explain in detail in the following section, has to do with the 'citizenship regime' in Turkey, insofar as it is the republican model of citizenship that has constituted the ideological foundation for the actor-like quality of civil society and its identity formation. In other words, without analyzing critically and problematizing the republican model of citizenship in which civil society in Turkey is embedded, we cannot understand why most of the civil society organizations contain normatively-loaded discourses and strategies, rather than preferring to act as issue-specific organizations.

\section{Civil Society and the Changing Notion of Citizenship in Turkey}

A quick glance at the literature on civil society indicates that the activities of civil society manifest themselves in the relationship between state and citizenry. In other words, what makes the notion of civil society so integral to such a diverse array of state-society relations is its direct articulation to the notion of citizenship. In this sense, it is the question of citizenship that should be taken into account in the analysis of civil society, in order to account for the possibility of the use and the abuse of civil society. In this section we elaborate the basic defining characteristics of the established notion of Turkish citizenship as they are related to the issues of civil society and democracy in Turkey. However, we think that it is necessary pause here and redirect our attention briefly to the conceptual formation of citizenship, in order to have an analytical framework for an adequate analysis of the republican model of citizenship in Turkey.

Even though defining citizenship is itself a political activity and hence it means different things to different people (Blackburn, 1994), what is often very common to these varying definitions is related to the three dimensions that citizenship involves: status, identity, and activity (Kymlicka and Norman, 2000). A person's citizenship status is defined largely by a discourse of the legal rights and duties that actually operate between citizens and the state. A person's 
citizenship identity is represented by membership in one or more political communities which are often compared with other more particular identities based on race, ethnicity, religion, class, gender, and so on. Finally, a person's citizenship activity (virtue) is seen essential for a responsible citizenship which requires some 'social capital' such as the ability to trust, the willingness to participate, or the sense of justice. Although the nature and dynamics of civil society in any given country is directly conditioned by each of these three constituting elements of citizenship, among them the aspects of status and activity are the main elements which link the citizenry to civil society.

Central to the status aspect of citizenship is the notion of 'citizenship rights' Historically and broadly speaking, and with reference to its Western experience since the eighteenth century, we can suggest that firstly the establishment of civil rights, second, that of the political rights, and then finally, that of the social and economic rights; all have directly contributed to the development of civil society. As Marshall (1965) described them, these three different types of rights are considered as the main elements of our modern citizenship. The civil rights are 'necessary for individual freedom, such as liberty of the person, freedom of speech, thought and faith, the right to own property and to conclude valid contacts, and the right to justice'. The political rights are related to participation 'in exercise of political power, as a member of a body of invested with political authority or as an elector of the members of such body'. The social and economic rights refer to 'the whole range from the right to a modicum of economic welfare and security to the right to share to the full in the social heritage and to live the life of a civilized being according to the standards prevailing in the society'.

There is no room for doubt that the virtue side of citizenship is extremely important and determining factor in the formation of civil society. As elaborated by Galston (1991), there are four types of civic virtues which are essentials not only for a well functioning modern citizenship but also for a flourishing civil society. These are regarded as the general virtues (courage, law-abidingness, loyalty), the social virtues (independence, open-mindedness), the economic virtues (work ethic, capacity to delay self-gratification, adaptability to economic and technological change), and the political virtues (capacity to discern and respect the rights of others, willingness to demand only what can be paid for, ability to evaluate the performance of those in office, willingness to engage in public discourse). What is important here is the social fact that how a citizenship regime treats its status and virtue aspects is in fact a reflection of its commitment to civil society. This fact also indicates that through its understanding of civil, political, social and economic rights, as well as its approach to the general, social, economic, and political virtues, a state is able to define the sort of civil society it projects. In other words, a state may use its citizenship regime to define the borders and the boundaries of its civil society.

If we return to the question of civil society in Turkey, and analyze it from this theoretical-analytical framework, it becomes clear that the changing nature of civil society goes hand in hand with the changing dynamics of the citizenship in the country. Since its establishment the Turkish Republic has been guided by a series of rationales that view citizenship as serving goals and practices of a 
universal kind reflected in Western political and philosophical tradition (Icduygu et al., 1999). In these rationales, a civic-republican understanding has been prevalent in the formation of Turkish citizenship (Soyarik, 2000). The emphasis has been on duty rather than right, and citizenship is considered to be a social practice rather than status. As we argued elsewhere (Keyman and Icduygu, 2003), this gives us the picture of the principle of 'militant/virtues citizenship', in which the national-secular identity is assumed to act in accordance with the organic vision of society, that is, as a citizen-subject who is willing to defer his/her rights until the point where he or she finishes his/her duties to the state, even though he or she knows that that point will never come. In this sense, the citizen is militantly active in the process of serving for the making of modern Turkey, and is virtuous in his/her will to put the public good before individual interest, his/her service for society before individual freedom, his/her national identity before difference, and his/her acceptance of cultural homogeneity before pluralism. However, it should be pointed out that the militant citizen is only active in terms of its duties to the state, but passive with respect to its will to carry the language of rights against state power.

As the Kemalist Republican ideology has tried to carefully construct the modern concept of citizenship with its own peculiar characteristics, there have not been many occasions in which the particular notion of citizenship is questioned and challenged. The Turkish citizenship has received renewed interest in the last 10 years, in a time when we have also observed the impacts of globalization on Turkish society. This coincidence is often interpreted empirically in the following way: 'as the implications of the idea of globalization are assessed particularly in terms of the possibilities for the governance of the international system' (Thompson, 1999) but not of the separate national entities, the conventional conception of Turkish citizenship (as a national identity and/or activity) can no longer play its unifying function, nor is it capable of translating abstract status to concrete rights. It is argued, in this context, that in a globalizing world the Turkish state is no longer able to operate and maintain its citizenship policies and practices as a result of both external factors (international migrations) and internal affairs (ethnic and religious revivals) (Icduygu and Keyman, 2000).

Of course, both 'international migrations' and 'ethnic and religious revivals' are not new phenomena. Nor are they the developments specific to the global era. But they are embedded in the process of globalization and generate important impacts on the notion of citizenship in two related ways: as directly puzzling the established notion of citizenship and as deeply contributing to the flourishing civil society. In the case of the former, as noted by Kastoryano (2000), international migration leads to an institutional expression of multiple citizenship, where the country of origin becomes a source of identity, the country of residence a source of status, and the emerging transnational space, a space of virtues combining the two or even more countries. Related to this argument, and in the case of the latter, it is suggested that contemporary international migration introduces a new mode of participation in public life both on national and international levels, and consequently 'reflects the internationalization of civil society' (Pellerin, 1996). Of course, here debating the international migration 
and citizenship issues does not only directly refers to the core debates of the politics of identity/difference under the concept of citizenship. But it practically relates the migration-based debate to the debate on identity politics.

For instance, there is clear evidence that the emigration of Turkish citizens itself has contributed to the revival of Kurdish nationalism and political Islam in the context of a diaspora formation (Sayari, 1986; Abadan-Unat, 1997). On the other hand, as noted before, the 1990s have witnessed the fact that the previously excluded peripheral identities began to question the fabricated and imposed monolithic republican citizenship in Turkey. Thus, civil society has become a site where identity-based diversity conflicts took place, and involve actors ranging from democratic forces to non-democratic communitarian political discourses. An outcome of this process has been the enlargement of civil society, but not necessarily conducive to democratization. With this background, one can conclude that the evolving nature of civil society in Turkey are very much conditioned by the country's internal dynamics, or inside, and its external relations, or outside. It is, therefore, very obvious that one should capture the developments in civil society in the context of global restructuring. In other words, one could not easily understand 'the relationship of the state to its civil society with no or minimal recognition of the existence of other states' (Taylor, 1996) and that of globalization.

\section{Conclusion: The Possibility of Democracy in Turkey}

If we can make a distinction between 'globalization from above' and 'globalization from below' (Falk, 1993), we could argue that civil society in late-modern times has the potential to play an important role for the possibility of democratic governance, by providing a space of deliberation for societal forces to transfer their interests and demands to political society. In this sense, as an area of political activity 'from below', civil society constitutes a necessary condition for democratizing the state-centric world. This role has to be supported both politically and normatively, not only in terms of global politics, but also with respect to national and local political units.

The positive role of civil society in the process of democratization concerns also the question of citizenship, since it contributes to the emergence of the crisis of the republican model of citizenship in Turkey, as well as its enlargement to the extent of including identity claims. In this sense, as a site of politics from below, civil society creates pluralism in a society, which has been constructed discursively as organic and nationally homogenous. In this chapter, we have argued that this quality of civil society has to be supported, but with an important reservation that there is no causal link between pluralism and democracy. As we have demonstrated, pluralism can also be articulated by religious and ethnic fundamentalism, which denounces democracy from the outset. This means that civil society as a space of pluralism can easily be simultaneously 'used' and 'abused' by fundamentalist discourses to strengthen their communitarian visions of society. These discourses have used civil society in their challenge to the republican model of citizenship in the name of pluralism, and at the same time abuse it by rendering it a functional means by which to realize 
their own communitarian strategies to become a hegemonic vision of Turkish society.

In this context, we have suggested that civil society should not be approached as a self-glorified phenomenon of late modernity. Instead, we have to view it from a critical point of view, as a necessary condition for democratization, and attempt to find ways of transforming it into a space of 'democratic deliberation'. The first step for this transformation is to situate civil society in a globalhistorical context in a way to approach it critically. To do so, we believe, has the potential to create a suitable methodological starting point to search for the possibility of building a 'democratic consensus' between state and civil society, identity and difference, and the self and the other. And it is in this attempt that the possibility of democracy in Turkey lies.

\section{Notes}

1. For details, see Beck (1998).

2. For an extensive survey of the activities of civil society organizations in the areas related to the human condition, see CIVICUS (1999).

3. It should be pointed out that this argument is not only a theoretical argument but also a thematic and empirical argument which we have extrapolated from our research on civil society organizations in Turkey, which was based upon in-depth interviews with the leaders of various effective civil society organizations, and a comprehensive reading of their publications. This research, which also included economic actors and popular culture, will be published as: Özbudun, E. and Keyman, E.F. (2002) 'Cultural globalization in Turkey', in: P.L. Berger and S.P. Huntington (Eds), Many Globalizations (Oxford, Oxford University Press), pp. 296-321.

4. This section is in fact the documentation of the in-depth interviews E.F. Keyman has done with the leaders of a number of important and effective civil society organizations in Turkey. For more detail, see Öbudun and Keyman (2002), pp. 312-16.

5. This document can be seen at $<$ http://www.deltur.cec.eu.int $>$.

6. This document can be accessed at $<$ http://www.abgs.gov.tr $>$.

7. See the following documentary sources, all of which have been published by the Turkish History Foundation in Istanbul, namely, as Civil Society Organizations in Turkey (1998), Civil Society Organizations in Istanbul (1998), and The Effective and Primary Civil Society Organizations (1998).

\section{References}

Abadan-Unat, N. (1997) 'Ethnic business, ethnic communities, and ethno-politics among Turks in Europe', in: E.M. Ucarer and D.J. Puchala (Eds), Immigration into Western Societies (London, Pinter).

Beck, U. (1998) The Reinvention of Politics (London, Polity).

Blackburn, R. (1994) 'Introduction: citizenship today', in: R. Blackburn (Ed.), Rights of Citizenship (London, Mansell).

CIVICUS (1999) Civil Society at the Millennium (West Hartford, Kumarian Press).

Dower, N. (1998) World Ethics (Edinburgh, Edinburgh University Press).

Ehrenberg, J. (1999) Civil Society (New York, New York University Press).

Falk, R. (1993) 'The making of global citizenship', in: J. Brecher et al. (Eds), Global Visions: Beyond the New World Order (Montreal, Black Rose Books).

Galston, W. (1991) Liberal Purposes: Goods, Virtues, and Duties in the Liberal State (Cambridge, Cambridge University Press).

Giddens, A. (1987) The Consequences of Modernity (Stanford, Stanford University Press).

Göle, N. (1994) 'Toward an autonomization of politics and civil society in Turkey', in: M. Heper and A. Evin (Eds), Politics in the Third Turkish Republic (Boulder, Westview).

Hale, W. and Avci, G. (2001) 'Turkey and the European Union: the long road to membership', in: B. Rubin and K. Kirisci (Eds), Turkey in World Politics (Boulder, CO, Lynne Reinner). 
Held, D. et al. (1999) Global Transformations (London, Polity).

Icduygu, A. and Keyman, E.F. (2000) 'Globalization, migration and security: the Turkish Case', Global Governance, 6, pp. 165-83.

Icduygu, A. et al. (1999) 'What is the matter with citizenship? A Turkish debate', Middle Eastern Studies, 35, pp. 187-208.

Kastoryano, R. (2000) 'Settlement, transnational communities and citizenship', International Social Science Journal, 165, pp. 307-12.

Keyman, E.F. (1997) Globalization, State and Identity/Difference (NJ, Humanities Press).

Keyman, E.F. (2000a) Türkiye ve Radikal Demokrasi [Turkey and Radical Democracy] (Istanbul, Alfa).

Keyman, E.F. (2000b) 'Globalization, civil society and Islam: the question of democracy in Turkey', in: J. Jenson and B. de Sousa Santos (Eds), Globalizing Institutions (Aldershot, Ashgate).

Keyman, E.F. and Icduygu, A. (2003) 'Globalization, migration and citizenship: the case of Turkey', in: E. Kofman and G. Youngs (Eds), Globalization, Theory and Practice (London, Pinter).

Kirisci, K. (2002) Justice and Home Affairs, Issues in Turkish-EU Relations (Istanbul, Tesev Publication).

Koh, H.H. and Slye, R.C. (Eds), (1999) Deliberative Democracy and Human Rights (New Haven, Yale University Press).

Kymlicka, W. and Norman, W. (2000) 'Citizenship in culturally diverse societies: issues, contexts, concepts', in: W. Kymlicka and W. Norman (Eds), Citizenship in Diverse Societies (Oxford, Oxford University Press).

Marshall, T.H. (1965) 'Citizenship and social class', in: T.H. Marshall (Ed.), Class, Citizenship and Social Development (New York, Anchor Books).

Pellerin, H. (1996) 'Global restructuring and international migration: consequences of the globalization of politics', in: E. Kofman and G. Youngs (Eds), Globalization, Theory and Practice (London, Pinter).

Sayari, S. (1986) 'Migration policies of sending countries', Annals, 485, pp. 87-97.

Schechter, M. (Eds) (1999) The Revival of Civil Society (London, Macmillan).

Soyarik, N. (2000) 'The citizen of the state and the state of the citizen: an analysis of the citizenization process in Turkey', unpublished PhD thesis, Department of Political Science, Bilkent University, Ankara.

Strange, S. (1992) Retreat of the State (Oxford, Cambridge University Press).

Taylor, P.J. (1996) 'The modern multiplicity of states', in: E. Kofman and G. Youngs (Eds), Globalization, Theory and Practice (London, Pinter).

Thompson, G. (1999) 'Introduction: situating globalization', International Social Science Journal, 160, pp. 139-52. 